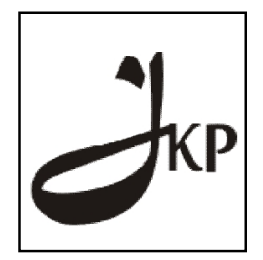

Jurnal Konseling dan Pendidikan

ISSN Cetak: 2337-6740 - ISSN Online: 2337-6880

http://jurnal.konselingindonesia.com

Volume 3 Nomor 3, November 2015, HIm 62-66

Info Artikel:

Diterima 04/10/2015

Direvisi 18/11/2015

Dipublikasikan 28/11/2015

\title{
PENANAMAN KONSEP MEMBACA AWAL MENGGUNAKAN ALAT PERAGA BERUPA KARTU HURUF DALAM MATA PELAJARAN BAHASA INDONESIA DI SDN 12 NAN SABARIS
}

Mimi Suharti

\begin{abstract}
Learning to read and write at primary school level is the main staple for Indonesian lessons, if students do not have the ability to read and write at an early stage, it will be very difficult for any lesson. Results of preliminary observations at 12 Nan Primary School Sabaris shows that there are some constraints faced by teachers in the learning process. One problem is difficult to instill the concept of reading and writing in students. The purpose of this action research are (1) to determine the extent to which the use of learning resources in the form of cards of letters and syllables and words can influence the level of student ability in assembling verbatim and read (2) to improve the ability of students to practice reading by using the card shared-card teacher said. Data obtained through tests and usage observation guide, the data is processed by a percentage. Results of the analysis of the data obtained in the first cycle of learning success; $61.00 \%$, and the second cycle; amounting to $81.50 \%$. So it showed no increase student learning from the first cycle to the second cycle. Thus the letter card usage can improve the understanding of stringing words and reading in students. This is evident from the enthusiasm with studentsmenyususun verbatim via encrypted card.
\end{abstract}

Keyword: Improved performance, the use of props such as card letters.

Copyright (C) 2015 IICET (Padang - Indonesia) - All Rights Reserved

Indonesian Institute for Counseling, Education and Theraphy (IICET)

\section{PENDAHULUAN}

Berdasarkan observasi pendahuluan pada kelas I SDN 12 Nan Sabaris, seperti SDN 12 Nan Sabaris, terdapat beberapa kendala yang dihadapi guru dalam pembelajaran Bahasa Indonesia. Salah satu kendalanya adalah dalam mengajarkan konsep pengenalan kata-kata yang disusun menjadi kata yang bermakna. Menurut para guru, pengenalan kata-kata yang disusun menjadi kalimat sederhana pada siswa sangat sulit. Kesulitan ini disebabkan sulitnya siswa membaca dengan lancar dan masih banyak kata-kata yang belum dikenal, alat peraga yang masih kurang, referensi yang kurang, waktu terbatas, dan jam mengajar guru cukup padat.

Dari hasil wawancara dengan para guru, SDN 12 Nan Sabaris juga diperoleh keterangan bahwa kartu huruf harus sebanyak mungkin disediakan agar siswa dalam belajar dapat dengan leluasa menggunakan kartu tersebut karna jumlahnya yang memadai. Dalam proses pembelajaran dengan menggunakan kartu akan membuat siswa senang dengan menyusun kata dan merangkainya menjadi kalimat yang sederhana, karna mereka bisa melihat dan menggunakan kartu itu secara langsung dan telah diacak. Menurut Sukmadinata (1988), guru yang baik adalah guru yang berhasil dalam pengajaran, yaitu guru yang dapat mempersiapkan siswa untuk mencapai tujuan pembelajaran sesuai dengan yang dirumuskan dalam kurikulum. Sudah banyak tulisan yang menyoroti tentang membaca pemula, tetapi penelitian-penelitian tersebut belum menyentuh langsung tentang upaya peningkatan cara membaca cepat dan efektif. Proses pembelajaran dengan metode ceramah dalam mata pelajaran Bahasa Indonesia cenderung membuat siswa menjadi pasif dan tidak ada keinginan siswa untuk mencoba merangkai kata karna tidak adanya kartu yang akan disusun menjadi kalimat sederhana dalam belajar. Dengan demikian, mempelajari bahasa khususnya dalam merangkai kata dengan alat peraga diperlukan proses pembelajaran dengan menggunakan pendekatan keterampilan proses. Pendekatan keterampilan proses melatih siswa untuk melakukan pengamatan dan mencoba secara langsung masalah yang diamati dalam proses pembelajaran.

Menurut Funk dan Harlen (1993), keterampilan proses merupakan keterampilan intelektual yang dipergunakan untuk memproses informasi yang diperoleh dalam pembelajaran. Sebagaimana dimuat dalam Depdikbud (1994) bahwa pendekatan keterampilan proses adalah pendekatan dalam proses belajar mengajar yang 
menekankan kepada pembentukan keterampilan memperoleh dan mengkomunikasikan hasilnya. Dengan menggunakan pendekatan keterampilan proses, diharapkan mencapai sasaran belajar sesuai dengan tujuan kurikulum pengajaran seperti dikemukakan oleh Bloom meliputi aspek pengetahuan (cognitive domain), aspek sikap (affective domain), dan aspek keterampilan (psychomotor domain) (Darmodjo dan Kaligis, 1992). Dari pendapat para ahli di atas, dapat disimpulkan bahwa, pendekatan keterampilan proses merupakan pendekatan yang dianggap paling tepat untuk mata pelajaran bahasa Indonesia.

Dalam penelitian Sarjono (2000) dinyatakan, penerapan keterampilan proses siswa sangat kurang sehingga siswa menunjukkan ketidakmampuan mengekspresikan ide-ide cara dengan mereka sendiri. Pada sisi lain, juga terlihat bahwa rata-rata nilai membaca dan menulis siswa dibawah kriteria yang telah ditentukan.

Berdasarkan gejala-gejala tersebut di atas, diperlukan peningkatan aktifitas membaca secara rutin dan berkelanjutan dengan menggunakan alat peraga yang memadai bagi siswa, dan pelaksanaannya dalam pembelajaran dilakukan diruang perpustakaan agar lebih leluasa untuk menyusun dan merangkai kata menjadi sebuahkalimat sederhana atau diruang kelas. "Membaca merupakan suatu prosesmenyusunhuruf demi huruf yang bermakna, yang kemudianbisa dilukiskan lambang-lambang grafik yang menggambarkan suatu bahasa yang dapat dipahami orang lain" (Sumanto,1987: 21). Wardana (1990:15) berpendapat bahwa "membaca adalah keseluruhan rangkaian kegiatan seseorang dalam menyebutkan simbol yang tertulis dalam bahasa tulis yang mempunyai arti sesuai dengan lambang atau huruf yang ditulis, sehingga seseorang akan bisa menangkap makna dari apa yang tertera". Selanjutnya, Lado (1964:143) menjelaskan tentang menulis, bahwa, "menulis adalah menyusun tanda-tanda tulis (graph symbols) yang menyatakan suatu bahasa yang diketahui oleh seseorang sehingga orang lain dapat membaca tanda-tanda tulis itu jika mereka mengenalnya dan mengerti bahasanya". Ahli lain, Hearton dalam Diknas (2007:3) mengungkapkan,

"Menulis adalah kegiatan menyusun kata-kata menjadi kalimat secara benar sesuai dengan kaidah tata bahasa, kemudian menghubung-hubungkan kalimat tersebut sehingga berbentuk suatu tulisan yang saling berhubungan yang dapat mengkomunikasikan pikiran dan ide penulis tentang suatu topik tertentu”.

Byrne dalam Diknas (2007:3) juga menguraikan "menulis tidak hanya membuat satu kalimat atau beberapa kalimat yang berhubungan, tetapi menghasilkan serangkaian kalimat yang teratur yang berhubungan satu dengan yang lain dan dalam gaya tertentu”. Berdasarkan pendapat-pendapat di atas dapat disimpulkan bahwa menulis adalah kegiatan menyampaikan gagasan kepada orang lain melalui tulisan. Tapisebelumseseorangbisa menulis, maka modal utamanya adalah membaca, jika tidak bisa membaca, bagaimana seseorangakanmenulisapa yang menjadibuah.

Dari latar belakang dan landasan teori di atas, masalah dalam penelitian dirumuskan sebagai berikut : (1) Pada kelas awal permulaan belajar membaca, dalam kenyataannya siswa masih banyak yang belum kenal dengan huruf (2) Penggunaan metode pembelajaran membaca dan menulis selama ini kurang bervariasi, sehingga prestasi yang dicapai masih rendah dan tidak sesuai dengan yang diharapkan. (3) Untuk membaca diperlukan pengenalan terhadap huruf-huruf yang akan dirangkai menjadi suku kata dan kata yang bermakna (4) Masih kurangnya minat siswa untuk membaca dan menulis

Dari latar belakang dan rumusan masalah tersebut, maka tujuan penelitian ini adalah (1) Bagaimanakah upaya meningkat kemampuanmembacadanmenulisbagikelaspermulaan di SDN 12 Nan Sabaris ? (2) Apakah dengan menggunakan alat peraga berupa kumpulan huruf-huruf yang bisa diacak kemudian disusun untuk menjadi sebuah kata yang bermakna dapat meningkatkan minat siswa untuk belajar membaca dan menulis ?

\section{METODE PENELITIAN}

Penelitian ini adalah penelitian tindakan kelas (classroom action research), dilaksanakannya PTK kelas I di SDN 12 Nan Sabaris, karena kendala yang muncul dalam proses pembelajaran seperti kuranglancarnyasiswamembacadanmenulis. Untuk mengatasi hal tersebut, maka perlu upaya perbaikan proses pembelajaran oleh guru, sebab hanya gurulah yang paling tahu tentang kemampuanmembaca kelas yang dikelolanya. Lewin (dalam Kemmins dan McTaggart, 1988) mendeskripsikan Penelitian Tindakan Kelas sebagai tindakan berkelanjutan dari langkah-langkah berbentuk spiral, setiap langkah (siklus) berisi perencanaan, pelaksanaan tindakan, observasi (evaluasi), dan refleksi tindakan. Penelitian ini dilakukan secara kolaborasi antara peneliti dengan kelas I SDN12 Nan Sabaris. Penelitian ini berlangsung 2 siklus, setiap siklus terdiri atas 4 tahap, yaitu (1) tahap perencanaan, meliputi : pembekalan kepada guru, penyusunan model pembelajaran, penyiapan 
instrumen tes (pretes, postes), lembar observasi dan membentuk kelompok belajar siswa, (2) tahap pelaksanaan tindakan, meliputi: pelaksanaan kegiatan dari perencanaan yang dibuat, (3) tahap observasi, yaitu pengamatan dari pelaksanaan tindakan melalui pedoman observasi, dan (4) tahap refleksi, yaitu menganalisis dan memberi pemaknaan dari pelaksanaan tindakan, sehingga dapat dibuat perencaan tindakan pada siklus berikutnya.

Data dalam penelitian ini dikumpulkan dengan menggunakan alat tes dan pedoman observasi. Tes digunakan untuk memperoleh data tentang peningkatan kemampuanmembacadanmenulis siswa. Tes yang digunakan terdiri atas 10-20 suku kata soal pada setiap siklus, sehingga jumlah soal dari kedua siklus berjumlah 40 suku kata. Agar dalam penyusunan tes dapat mengukur aspek yang diperlukan dan sesuai dengan pokok dan subpokok bahasan yang diajarkan, maka terlebih dahulu disusun kisi-kisi tes (Sudjana, 1989). Selanjutnya tes yang telah disusun dilakukan uji coba terlebih dahulu agar tes dalam instrumen dapat dipergunakan untuk menyaring data secara akurat. Kaitannya dengan uji coba tes tersebut maka dilakukan (a) uji validitas, (b) uji reliabititas, (c) uji tingkat kesukaran, dan (d) uji daya beda. Selanjutnya setelah tes tersebut memenuhi syarat sesuai dengan persyaratan tes yang baik, barulah tes tersebut digunakan menjaring data dalam penelitian, seperti mengadakan pretes dan postes pada setiap pertemuan. Siswa yang dianggap tuntas belajar bila telah mencapai nilai 70 ke atas, siswa yang dapat nilai kurang dari 70 dinyatakan belum tuntas belajar. Pengadaan postes dilaksanakan pada setiap akhir siklus, sedangkan untuk mengamati kegiatan guru dan siswa digunakan pedoman observasi. Untuk mendukung hasil pengamatan, peneliti juga melakukan perekaman kegiatan proses pembelajaran dengan menggunakan kamera foto.

Data yang telah terkumpul dianalisis dengan rumus persentase. Selanjutnya, nilai yang diperoleh siswa dicocokkan ke dalam tabel konversi nilai dengan skala 5. Hasil analisis ini digunakan untuk mencari ketuntasan belajar. Menurut Depdikbud (1994) ketuntasan belajar secara klasikal sebesar 85\%, dari siswa memperoleh nilai 65 atau $65 \%$, artinya siswa baru dapat dikatakan tuntas bila siswa telah mendapat nilai minimal 75 . Bila siswa memperoleh nilai kurang dari 75 dianggap belum tuntas belajar, selanjutnya bagi siswa yang bersangkutan dimasukkan ke dalam 1 atau 2 kelompok tergantung dari jumlah siswa yang belum tuntas belajar. Siswa inilah yang mendapatkan perhatian (fokus) dari guru saat pelaksanaan tindakan pada siklus-siklus berikutnya.

\section{HASIL PENELITIAN DAN PEMBAHASAN Hasil Belajar}

Sebelum penelitian yang sebenarnya dimulai, terlebih dahulu peneliti dan siswa kelas I pada tahun 2014/2015 tepatnya 9 bulan April 2015, mengadakan semacam lomba menyusun suku kata dalam bentuk permainan, di halaman SDN 12 Nan Sabaris. Tujuannya adalah untuk menguji kemampuan siswa membaca dan mengenal suku kata dan kata-kata dalam kartu, sehingga nantinya diharapkan tumbuh semangat belajar bagi siswa karna adanya permainan menyusun suku kata menjadi kata dan kalimat sederhana yang bermakna.

Selanjutnya penelitian dilaksanakan dalam 2 siklus. Pada siklus I dilaksanakan 3 kali pertemuan, membahas kartu kata yang akandisusunmenjadisebuahkalimatsederhana, masing-masing pertemuan memerlukan waktu 3 x 35 menit. Pembagian waktunya 15 menit motivasi awal dari guru dan pembagian kelompok, 70 menit kegiatan di kelas serta presentasidanmenunjukkankemampuanmerangkai kata danmembaca di depankelas 20 menit kemudian di akhiri dengan rangkuman oleh guru. Setiap siklus diawali dengan pretest dan pada akhir siklus diadakan postes. Hasil pengamatan pada siklus I adalah sebagai berikut, yakni (a) guru telah memulai pelajaran dengan memberi motivasi pada siswa dan mengakhiri dengan membuat rangkuman, (b) pada setiap kegiatan, guru telah berusaha mendampingi siswa, (c) kegiatan diskusi siswa masih kurang aktif terutama kelompok 2 \& 4 dan yang aktif kelompok $1 \& 3$ (d) dari hasil postes ada sebanyak 20 orang yang telah tuntas 7 orang dan 13 orang yang belum tuntas. Hasil refleksi pada siklus I adalah (a) keaktifan siswa dalam kerja kelompok kurang, (b) siswa belum mampu merangkai suku kata menjadi kalimat sederhana, (c) guru mendorong siswa berani mengajukan dan menjawab pertanyaan,(d) terdapat 35\% siswa telah tuntas, dan $65 \%$ siswa belum tuntas.

Dari refleksi tindakan pada siklus I disusun rencana tindakan siklus II sebagai berikut: yakni (1) guru merubah susunan kelompok dengan memasukkan siswa yang kurang berhasil menjadi 2 kelompok (kelompok I dan kelompok 2), (2) memasukkan siswa yang belum tuntas ke dalam 2 kelompok tadi, (3) guru harus lebih memfokuskan perhatian kepada siswa yang belum tuntas, (4) guru menyarankan siswa bekerja lebih sistematis, dan (5) siswa diwajibkan mengenal suku kata yang akan dirangkai menjadi kata sehari sebelumnya.

Pada siklus II, dilaksanakan 3 kali pertemuan, masing-masing 3 x 35 menit. Materi yang dibahas adalah kartu yang terdapat di depan siswa yang sudah dibagikan perkelompok belajar dan menyususn kegiatan yang 
meliputi: Pembagian waktu dan teknik pelaksanaannya secara umum sama dengan siklus I. Hasil pengamatan tindakan pada siklus II adalah sebagai berikut: yakni (a) guru melaksanakan proses pembelajaran dengan baik, (b) kerja kelompok siswa berjalan dengan baik, (c) siswa aktif menyususn kata menjadi kalimat dan membacanya dengan benar, (d) aktivitas kelompok yang menjadi fokus penelitian berjalan dengan baik dan aktif, (e) dari hasil postes terdapat $90 \%$ (18 orang yang telah tuntas), sedangkan 2 orang belum tuntas belajar. Refleksi tindakan pada siklus II sebagai berikut: (a) kerja sama kelompok dan keaktifan berjalan dengan baik, (b) kelompok yang menjadi fokus penelitian mampu meningkatkan kemampuan membacanya terhadap kata-kata acak yang disusun menjadi kalimat sederhana, (c) tingkat ketuntasan belajar secara klasikal mencapai $90 \%$ atas banyak 18 orang, berarti sudah berada di atas $80 \%$, dan (d) pelaksanaan siklus berikutnya tidak diperlukan lagi.

Dari kedua siklus tersebut diperoleh hasil secara berturut-turut yaitu (a) 65\% pada siklus I, (b) $90 \%$ pada siklus II. Artinya ada peningkatan kemampuan dan hasil belajar membaca dan menulis yang dikuasai oleh siswa kelas I SDN 12 Nan Sabaris dalam proses pembelajaran Bahasa Indonesia. Dengan demikian, hipotesis yang diajukan berbunyi Penggunaan alat peraga berupa kartu huruf untuk melatih kemampuan membaca dan merangkai kata dapat meningkatkan kemampuan siswa dalam membaca dan menulis bagi siswa kelas I SDN 12 Nan Sabaris dapat diterima karena telah terbukti kebenarannya.

\section{PEMBAHASAN}

Penggunaan alat peraga berupa kartu hurufdalam mata pelajaran Bahasa Indonesia dapat meningkatkan kemampuanmerangkai kata danmembaca pada siswa. Hal ini telah terbukti dari hasil pelaksanaan tindakan pada setiap siklus seperti diuraikan dalam bab IV yaitu pada hasil penelitian. Dari data tersebut, terdapat peningkatan membacadanmenulis siswa yang sangat meyakinkan, artinya penggunaanalatperaga sangat mendukung bila dimanfaatkan dalam proses pembelajaran karena dapat mempercepat pemahamansiswauntukmengenaldanmerangkai kata sertamembaca pada kelas I SDN 12 Nan Sabaris. Temuan ini sesuai dengan pendapat Arief (1996) yang menyatakan penggunaan media dalam bentuk asli akan lebih bermakna bagi anak didik dan bagi pengembangan ilmu pengetahuan alam dibandingkan media bentuk model, gambar, dan sketsa.

Bila dibandingkan dengan temuan peneliti lain yang dirujuk, maka penelitian ini mempunyai karakteristik tersendiri, yaitu pemanfaatan kartu-kartuhuruf, suku kata dan kata yang dibuatdanditulispadakarton yang ada di lingkungan sekolah dalam upaya mempercepat pemahaman tentangbacaandari kata yang disusun siswa. Hasil penelitian ini bermanfaat bagi siswa, seperti (1) siswa memiliki keterampilan untuk mendapatkan ilmu yang berupa "keterampilan proses" atau metode ilmiah, (2) gairah belajar siswa meningkat, tercermin dari keaktifan siswa dalam melakukan kegiatan menyususn kata yang diacak di sekolah, dan (3) belajar menjadi bermakna, karena setelah konsepnya dipahami maka konsep tersebut lebih lama dapat diingat. Temuan ini didukung oleh pendapat Arikunto (1990) bahwa lingkungan sekolah merupakan sesuatu yang dekat dengan dunia siswa dan mudah dikenal dalam kehidupan sehari-hari, serta lingkungan sekolah merupakan tempat yang menunjang sebagian dari kebutuhan siswa.

Penelitian ini juga berguna bagi guru, karena (1) guru dapat memperdalam pendekatan dan metode yang digunakan, (2) guru menjadi lebih profesional, karena meningkatnya pengetahuan dan pemahaman tentang penelitian tindakan kelas. Temuan ini didukung oleh Susilo (2000) menyatakan bahwa guru yang terampil melaksanakan PTK adalah guru yang selalu mau meningkatkan proses pembelajaran yang dikelolanya.

Implikasi penelitian ini bagi sekolah adalah sekolah memiliki guru yang profesional dan sekolah dapat menambah koleksi tumbuhan yang berguna dalam proses pembelajaran, keindahan, kesejukan, dan pelestarian lingkungan. Tidak kalah penting artinya temuan ini bagi peneliti karena (1) dapat meningkatkan pengetahuan tentang PTK, (2) mengenal lebih dalam mata pelajaran Bahasa Indonesia di SD, dan (3) dapat merintis kerja sama kemitraan dengan sekolah dan guru.

Penggunaanalatperaga dapat meningkatkan kemampuan siswa dalam mengerjakan LKS secara berkelompok. Hal ini dapat terwujud karena pada setiap pelaksanaan tindakan, guru selalu membentuk kelompokkelompok yang terdiri atas lima sampai enam orang siswa, baru kemudian dibagikan kartu huruf. Kelompok ini tidak selalu tetap, karena pada setiap siklus selalu berubah susunan anggotanya. Perubahan ini bertujuan (a) memudahkan guru membimbing siswa, (b) membiasakan siswa bekerja secara berkelompok pada setiap orang, dan (c) meningkatkan keaktifan berdiskusi dengan susunan baru, serta siswa akan lebih bergairah belajar. 
Pada siklus I ada dua kelompok yang belum aktif seperti kelompok $2 \& 4$. Dari hasil pengamatan menunjukkan bahwa kelompok ini belum aktif untukmenyususn kata darikartuhuruf, belum dapat menyelesaikan tugas dengan tuntas dan belum mampu membuat kesimpulan dengan benar. Dentsch (dalam Lazarowith dan Slavin, 1984) menyatakan agar pembelajaran dapat berlangsung secara kerja kelompok, maka siswa harus mempersiapkan diri saling tergantung secara positif antara anggota kelompok lain.

Pada siklus II dengan diadakan perubahan susunan kelompok dan fokus guru lebih diarahkan kepada kelompok yang kurang tuntas, ternyata dapat meningkatkan aktivitas kelompok menjadi lebih baik dan aktif. Kenyataan ini terlihat pada (a) masing-masing mampu menyelesaikan tugasnya, dan (b) siswa telah berani mengajukan tampil untuk menyususn kata kemudia nmembacanya secara lantang di depankelasmemperesentasikanhasiltemuannya. Hal ini menunjukkan kerja sama kelompok dapat dibangun dari kesadaran masing-masing individu dalam kelompok. Temuan ini didukung pendapat Slavin (1986) bahwa ciri khusus yang membentuk belajar kelompok adalah metode ini mendorong siswa bekerja sama untuk belajar dan bertanggung jawab.

Dengan hasil tersebut berarti penggunaanalatperagadapatmeningkatkan kemampuan siswa membacadanmengerjakan tugas secara berkelompokataupunperorangan berada dalam kategori baik.

\section{PENUTUP}

Berdasarkan hasil penelitian dan pembahasan dapat disimpulkan sebagai berikut.

1. Penggunaanalatperagaberupakartuhuruf dalam proses pembelajaran dapat meningkatkan kemampuanmembacadanmenulisbagi siswa. Hal ini dibuktikan dengan terjadinya peningkatan ketuntasan belajar siswa pada setiap siklus, yaitu $65,00 \%$ pada siklus I, 81,50\% pada siklus II.

2. Ketuntasan belajar pada siklus II yaitu $81,50 \%$ telah melampaui dari standar baku yaitu $75 \%$ sehingga pembelajaran sudah dianggap tuntas.

3. Kerja sama kelompok semakin meningkat pada setiap siklus. Keberhasilan ini ditunjukkan dengan aktifnya siswa dalam diskusi kelompok dan diskusi kelas, sehingga pembelajaran menjadi lebih bermakna bagi siswa.

4. Guru semakin kreatif dan profresional dan pengembangan proses pembelajaran di kelasnya.

Berdasarkan kesimpulan di atas, dapat disarankan sebagai berikut.

1. Agar guru menggunakan sumber belajar berupa pengalaman siswa di sekolah dalam pembelajaran membaca dan menulis kata-kata dan pembelajaran kebahasaan lain yang relevan.

2. Agar guru dapat menggunakan alat peraga yang sesuai dengan materi ajar, dalam artikata, guru melakukan pembelajaran bukan hanya secara konvensional tetapi harus secara konstektual agar mudah dipahami oleh siswa.

3. Agar kepala sekolah dan pihak-pihak terkait menyarankan kepada guru yang dipimpinnya untuk menggunakan berbagai sumber belajar

4. Agar guru melanjutkan penelitian ini dalam bentuk PTK untuk mendapatkan hasil pembelajaran yang lebih baik

\section{DAFTAR PUSTAKA}

Atmazaki. 2006. Kiat-kiat Menyorong dan Penyunting. Padang : Citra Budaya.

A. Tabrani Rusyam. dkk. 1992.Pendekatan Dalam Proses Belajar Mengajar. Bandung : PT. Remaja Rosdakarya.

Diknas. 2003. Kurikulum 2004 Sekolah Menengah Pertama (SMP) Mata Pelajarn Bahasa dan Sastra Indonesia. Jakarta : Diknas.

Endraswara, Suwardi. 2005. Metode dan Teori Pengajaran Sastra. Yogyakarta: Buana Pustaka.

Muhardi dan Hasanuddin W.S. 2006. Prosedur Analisis Fiksi :Kajian Strukturalisme. Padang : Citra Budaya.

Nana Sudjana dan Ahmad Rivai. 1990. Media Pengajaran, (Penggunaan dan Pembuatannya). Bandung : CV Sinar Baru.

Syaiful Bahri dan Aswan Zain. 1995. Strategi Belajar Mengajar. Banjarmasin : Rineka Cipta.

Suharsimi Arikunto, dkk. 2006. Penelitian Tindakan Kelas. Jakarta : Bumi Aksara.

Suyatno. 2004. Teknik Pembelajaran Bahasa dan Sastra. Surabaya : Penerbit SIC. 